\title{
Influence of laser beam profile on light scattering by human skin during photometry by ellipsoidal reflectors
}

\author{
Bezuglyi M., Bezuglaya N., Kostuk S. \\ National Technical University of Ukraine «Igor Sikorsky Kyiv Polytechnic Institute», \\ Peremohy Ave., 37, Kyiv 03056, Ukraine \\ Received 16.01.2018 \\ Accepted for publication 20.02.2018
}

\begin{abstract}
The correct accounting of laser emitter parameters for improvement of diagnostic authenticity of methods of optical biomedical diagnostic is important problem for applied biophotonic tasks. The purpose of the current research is estimation of influence of energy distribution profile in transversal section of laser beam on light scattering by human skin layers at photometry by ellipsoidal reflectors.

Biomedical photometer with ellipsoidal reflectors for investigation of biological tissue specimens in transmitted and reflected light uses laser probing radiation with infinitely thin, Gauss-type and uniform cross-section profile. Distribution of beams with denoted profiles, which consist of 20 million photons with wavelength $632.8 \mathrm{~nm}$, was modeled by using of Monte-Carlo simulation in human skin layers (corneous layer, epidermis, derma and adipose tissue) of various anatomic thickness and with ellipsoidal reflectors with focal parameter equal to $16.875 \mathrm{~mm}$ and eccentricity of 0.66 .

The modeling results represent that illuminance distribution in zones of photometric imaging is significantly influenced by the laser beam cross-section profile for various thickness of corneous layer and epidermis in transmitted and reflected light, and also derma in reflected light. Illuminance distribution for adipose tissue in reflected and transmitted light, and also derma in transmitted light, practically do not depend of laser beam profile for anatomic thicknesses, which are appropriate for human skin on various sections of body.

There are represented results of modified Monte-Carlo simulation method for biomedical photometer with ellipsoidal reflectors during biometry of human skin layers. For highly scattered corneous layer and epidermis the illumination of middle and external rings of photometric images changes depending from the laser beam profile for more than $50 \%$ in transmitted and $30 \%$ in reflected light. For weakly scattering skin layers (derma and adipose layer) the influence of profile can be observed only for derma in reflected layer and is equal not more than $15 \%$.
\end{abstract}

Keywords: ellipsoidal reflector, laser, human skin, photometry, Monte-Carlo simulation.

DOI: $10.21122 / 2220-9506-2018-9-1-56-65$

\begin{tabular}{|c|c|}
\hline $\begin{array}{l}\text { Адрес для переписки: } \\
\text { Безугльй М.А. } \\
\text { Национальный технический университет Украиньл } \\
\text { «Киевский политехнический институт имени Игоря Сикорского», } \\
\text { пр. Победы,, 37, г. Киев 03056, Украина } \\
\text { e-таil: mikhail_bezuglyy@ukr.net }\end{array}$ & $\begin{array}{l}\text { Address for correspondence: } \\
\text { Bezuglyi M. } \\
\text { National Technical University of Ukraine «Igor Sikorsky Kyiv } \\
\text { Polytechnic Institute», } \\
\text { Peremohy Ave., 37, Kyiv03056, Ukraine } \\
\text { e-mail: mikhail_bezuglyy@ukr.net }\end{array}$ \\
\hline Для цитирования: & For citation: \\
\hline Bezuglyi M., Bezuglaya N., Kostuk S. & Bezuglyi M., Bezuglaya N., Kostuk S. \\
\hline $\begin{array}{l}\text { Influence of laser beam profile on light scattering by human skin during } \\
\text { photometry by ellipsoidal reflectors. }\end{array}$ & $\begin{array}{l}\text { Influence of laser beam profile on light scattering by human skin during } \\
\text { photometry by ellipsoidal reflectors. }\end{array}$ \\
\hline Приборы и методы измерений. & Devices and Methods of Measurements. \\
\hline 2018. - Т. 9, № 1. С. 56-65. & 2018 , vol. 9 , no. 1 , pp. $56-65$. \\
\hline DOI: $10.21122 / 2220-9506-2018-9-1-56-65$ & DOI: $10.21122 / 2220-9506-2018-9-1-56-65$ \\
\hline
\end{tabular}




\title{
Влияние профиля лазерного пучка на светорассеяние кожей человека при фотометрии эллипсоидальными рефлекторами
}

\author{
Безуглый М.А., Безуглая Н.В., Костюк С.А. \\ Национальный технический университет Украиньл \\ «Киевский политехнический институт имени Игоря Сикорского», \\ пр. Победы, 37, г. Киев 03056, Украина \\ Поступила 16.01.2018 \\ Принята к печати 20.02.2018
}

Корректный учет параметров лазерного излучателя для повышения диагностической достоверности методов оптической биомедицинской диагностики является важным для прикладных задач биофотоники. Целью данной работы являлась оценка влияния профиля распределения энергии в поперечном сечении лазерного пучка на светорассеянье слоями кожи человека при фотометрии эллипсоидальными рефлекторами.

Биомедицинский фотометр с эллипсоидальными рефлекторами для исследования образцов биологических тканей в проходящем и отраженном свете использует в качестве зондирующего лазерное излучение бесконечно тонкого, гауссового и равномерного профиля поперечного сечения. Распространение пучков обозначенных профилей, состоящих из 20 млн фотонов с длиной волны 632,8 нм, было промоделировано путем симуляции Монте-Карло в слоях кожи человека (роговом слое, эпидермисе, дерме и подкожной жировой ткани) различной анатомической толщины и эллипсоидальных рефлекторах с фокальным параметром 16,875 мм и эксцентриситетом 0,66.

Результаты моделирования показали, что распределение освещенности в зонах поля фотометрических изображений для различных толщин рогового слоя и эпидермиса в проходящем и отраженном слое, а также дермы в отраженном свете существенно подвержены влиянию профиля поперечного сечения лазерного пучка. Распределение освещенности для подкожной жировой ткани в отраженном и проходящем свете, а также дермы в проходящем свете, практически не зависят от профиля лазерного пучка для анатомических толщин, свойственных коже человека на различных участках тела.

Представлены результаты модифицированного метода симуляции Монте-Карло для биомедицинского фотометра с эллипсоидальными рефлекторами при биометрии слоев кожи человека. Для сильно рассеивающих рогового слоя и эпидермиса освещенность среднего и внешнего колец фотометрических изображений изменяется в зависимости от профиля лазерного пучка более чем на 50 \% в прошедшем свете и $30 \%$ - в отраженном. Для слабо рассеивающих слоев кожи (дермы и подкожной жировой ткани) влияние профиля заметно только для дермы в отраженном слое и не превышает $15 \%$.

Ключевые слова: эллипсоидальный рефлектор, лазер, кожа человека, фотометрия, Монте-Карло моделирование.

DOI: $10.21122 / 2220-9506-2018-9-1-56-65$

\begin{tabular}{ll}
\hline Адрес для переписки: & Address for correspondence: \\
Безугльй М.А. & Bezuglyi M. \\
Национальный технический университет Украиньл & National Technical University of Ukraine «Igor Sikorsky Kyiv \\
«Киевский политехнический институт имени Игоря Сикорского», & Polytechnic Institute», \\
пр. Победы, 37, г. Киев 03056, Украина & Peremohy Ave., 37, Kyiv 03056, Ukraine \\
e-таil: mikhail_bezuglyy@ukr.net & e-mail: mikhail_bezuglyy@ukr.net \\
\hline Для цитирования: & For citation: \\
Bezuglyi M., Bezuglaya N., Kostuk S. & Bezuglyi M., Bezuglaya N., Kostuk S. \\
Influence of laser beam profile on light scattering by human skin during & Influence of laser beam profile on light scattering by human skin during \\
photometry by ellipsoidal reflectors. & photometry by ellipsoidal reflectors. \\
Приборы и методы измерений. & Devices and Methods of Measurements. \\
2018. - Т. 9, № 1. С. 56-65. & 2018, vol.9, no. 1, pp. 56-65. \\
DОI: 10.21122/2220-9506-2018-9-1-56-65 & DOI: 10.21122/2220-9506-2018-9-1-56-65 \\
\hline
\end{tabular}




\section{Introduction}

Class of modern optical informational and measurement devices, which applies for noninvasive and low-invasive diagnostic of different indicators, conditions and diseases, use light-emitting diode or laser probing radiation with corresponding characteristics of energy and wavelength. Pulsioxymetry, glucose metering, chromometry, mexametery, laser Doppler flowmetry, and optical profilometry [1] create small by nomenclature, but the most numerous by production group of optical methods, which are widely used in biomedical and laboratory practice. Considering that mentioned methods use light, which is reflected and/or transmitted and the main light scattering organ is human skin, the evaluation of influence of its optical properties on the indicators of the registered light is important and actual problem.

In more complicated systems of optical noninvasive diagnostic (like optical diffuse or coherent tomography, confocal microscopy, and dermatoscopy) [2], there takes into consideration light scattering and light absorption properties of human skin during the process of medical visualization. Each of the mentioned methods allows estimation of skin integument structure in normal state or during pathologies in different depth and at different resolutions. The advantage of noninvasive research methods against traditional biopsy is not only the ability of fast receiving of cell image, tissue, and skin relief into mode, but also dynamical objectification of observation and evaluation of light therapy efficiency. Authors [1, 3] notes that interaction between light and skin is complicated due to the multilayer and multicomponent structures of skin. Corneous layer reflects $5-7 \%$ of incident radiation. Collimated beam of light transforms into diffusive owing to microscopic heterogeneity in the boundary of air and corneous layer. Significant part of light, reflected by the skin, creates due to backscattering by different skin layers (corneous layer, epidermis, derma and microvascular system). Absorption of scattered light by skin pigments provide quantitative information about concentration of bilirubin, melanin, water, saturation of hemoglobin with oxygen, actual content of different absorbers in tissues and blood, and this form the basis for the number of previously mentioned methods $[1,4]$. Significant penetration of visible and near infrared light through the skin inside the human organism, especially in the wavelength range of «therapeutic window» $(650-900 \mathrm{~nm})$, is the basis for number of phototherapy methods [5].

Devices and systems, which realize these methods, refers to the class of photometers, according to measuring parameters and technical essence. The construction of such devices is typical for applied optical systems. However, the reliability and accuracy of measured values is still problem. The first reason is the loss of useful optical signal. The reason for this is impossibility of total registration of scattered by biological tissue radiation by collecting aperture. The second reason is the mathematical model of optical radiation distribution. It ensures the interconnection of measurement results with physiological characteristics, but it not necessarily considers the features of measurement system based on photometer. Taking into account general operation principles of mentioned biomedical photometers, they can be equipped by the measuring core with the shape of ellipsoidal reflector (ER). Thus allow increasing of specific weight of registered optical signal [6]. Practical experience of real and modelled experiments reveal that proper selection of parameters of reflector, source and photodetector [7] allow selection of necessary configuration of measuring tool for solution of different problems of biomedical experiment. The one of necessary condition for consideration of interaction of optical radiation with biological media is collimating of incident radiation, similarly to biophotonics in general and method of ellipsoidal photometry in particular. That is the reason why the interest of the research is the profile of energy distribution of radiation source in transversal direction to the light propagation and its influence on the features of ray tracing [8] in the system «biological media + ellipsoidal reflector» and on spatial distribution of scattered light. The aim of the study was the evaluation influence of the laser beam profile on the light scattering by human skin layers at ellipsoidal photometry.

\section{Methods}

Output parameters of laser radiation source, such as spectral characteristics, divergence of the laser beam, average or continuous power, coherence degree and modes [3], significantly influences the optical properties, which describes the interaction of such radiation with biological media. Since determination of optical properties of biological media (BM) solves using inverse methods of biomedical analysis, the proper consideration of 
sourced parameters during solution of major problem will allow significant increasing of its accuracy. Considering the advantages, formulated in for photometers with ellipsoidal reflectors, among the direct methods of modelling of light propagation in BM the article authors singles out the Monte-Carlo method $[9,10]$. During this method realization, it is possible to consider such parameters of source like power and energy distribution in transversal modes. From the other side, spectral characteristics of laser radiation are included in optical coefficients of scattering and absorption, scattering anisotropy factor, and in refractive index, that characterizes BM sample. Considering the photometer construction with ER and their purpose, longitudinal profile of laser beam (direction diagram, divergence), which traditionally considers as Gaussian, do not provide diagnostically significant information, and in this research it is not examined.

Power distribution in laser beam defines by properties of active resonator, which an have different stationary configurations of electromagnetic field (modes and oscillation type), thus the change of field directions in orthogonal secant of beam in each of coordinates [11] can be considered for specific laser type of selected power. For single-mode laser transversal mode TEM00 of lower order is under the Gaussian law of intensity distribution around the central maximum (1). This transversal mode allow focusing of the laser ray into minimal spot with high power density:

$$
\frac{I(r)}{I_{0}}=e^{-2 r^{2} / r_{0}^{2}}
$$

where $I_{0}$ - intensity in the center of Gaussian beam; $r_{0}$ - radius of laser beam.

In the research there is represented analysis of influence of profile of main transversal mode with Gauss distribution. Additionally there considered cases with infinite thin beam and beam of finite diameter with uniform distribution (Figure 1). Practically, infinitely thin beam can be reached by using one or, in some cases, two diaphragms with small orifice diameter, placed in series. In this case, diameter of laser beam strives for zero. Gauss profile of main transversal mode corresponds to parameters of real laser sources without using of transmission optics, and beam radius determines by maximum value of intensity in beam center reduced on $\mathrm{e}^{2}$ times. Almost uniform distribution is resulted by using of thin plate of milk-glass and collimating optical system, increase of angular value of which corresponds to the output beam diameter, and suitable diaphragm, which acts as a spatial filter. Both critical cases of intensity distribution and Gauss transversal profile are axially symmetric and centered referring to receiving side of photodetector.

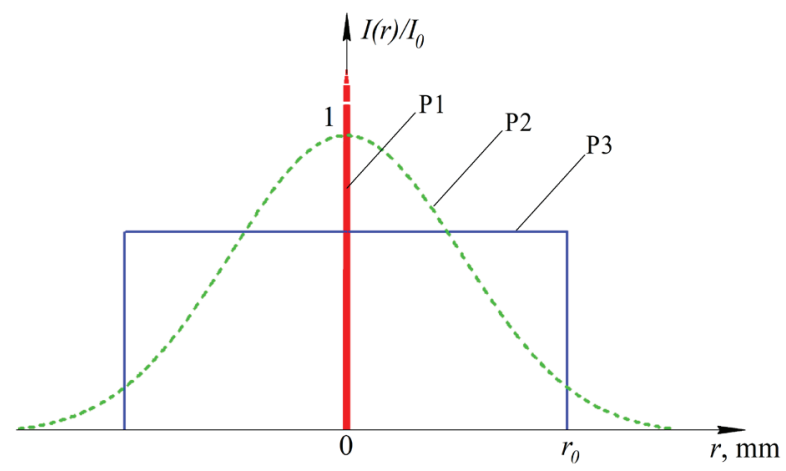

Figure 1 - Transversal distribution of laser power: $P 1$ infinitely thin beam; $P 2$ - Gauss section beam; $P 3-$ uniform intensity beam

The transition to values of laser source power (in case of continuous light emitting) and energy (in case of impulse light emitting) is possible if consider specific laser type and measurement method of these energy parameters. Considering numeric experiment of current research, it is assumed that nominal power of laser radiation is the graph functions situated under integral, and they are represented in Figure 1. At the same time incident radiation on experimental sample is considered the same for three examined cases of transversal profile of its distribution. At both anatomically and optically, human skin can be represented as single-layer organ, or multi-layer one with layer quantity up to 10 [12-14]. At the same time, separate layers are similar to each other, with minor differences in optical coefficients of scattering and absorption and the same refractive index [15]. For the research in this work there was selected fourlayered structure with optical properties represented in Table. At the same time the thickness range of upper mentioned layers corresponds to Ref. [16]. Analysis of optical properties describe the corneous layer and epidermis as strongly scattering layers in this structure. Dermis and adipose tissue are weakly scattering comparing to them.

Algorithmization of light propagation in multilayered BM by Monte Carlo method [10] include sequential considering of interactions of incident photon of initial weight with scattering (absorbing) center in separate layer. Results of modeling are coordinates of outgoing photon of reduced weight and directing cosines, which forms spatial distribution 
of scattered radiation in photo receiving plane of measuring system, considering mechanism of raytracing in system «BM+ER» [7]. At the same time there considers Fresnel conditions between media of human skin layers. Multi-layered skin concept considers that optical properties and thickness of corneous layer, epidermis, derma, and adipose tissue remain constant. That is the reason why the variation of real layers thickness cannot be considered, and it is time-consuming process to evaluate the influence of incident beam of rays on such structure. That's why in the research there was investigated the influence of energy distribution in transversal section inside the laser beam for separate layers of human skin in forward and backscattered light with using of mirror ellipsoid of revolution methods. As an informational-measuring system there was used photometer configuration (Figure 2), similar to experimental setup used in [7, 8], and Monte-Carlo simulation algorithm in system «BM+ER».

Optical properties of human skin layers

\begin{tabular}{lccccc}
\hline Human skin layers & $\mathrm{n}$ & $\mu_{\mathrm{a}}$ & $\mu_{\mathrm{s}}$ & $\mathrm{g}$ & $\mathrm{d}, \mathrm{mm}$ \\
\hline Corneous layer & 1.5 & 0.1 & 100 & 0.8 & $0.02 \ldots 0.62$ \\
Epidermis & 1.34 & 0.15 & 45 & 0.8 & $0.035 \ldots 0.726$ \\
Derma & 1.39 & 0.073 & 20 & 0.76 & $0.66 \ldots 4,76$ \\
Adipose tissue & 1.44 & 0.068 & 15 & 0.8 & $0.03 \ldots 8,38$ \\
\hline
\end{tabular}

In real photometer are used two monochrome CCD camera DMK-21 (Imaging Source) and objective optical system Tamron 13VM2812. In case when photodetector size corresponds to reflector entrance port diameter (double focal parameter) and is sensitive plane situated directly in its second focal plane, thus all rays passed out of the BM sample participate in formation of photometric image. As size of CCD matrix of camera are significantly smaller then entrance port, than at photometry uses matching optical system that project photometric image, which was formed in second focal plane, into photodetecting plane. Actually, in such case in formation of photometric image participates only rays, which interacts with reflectors.

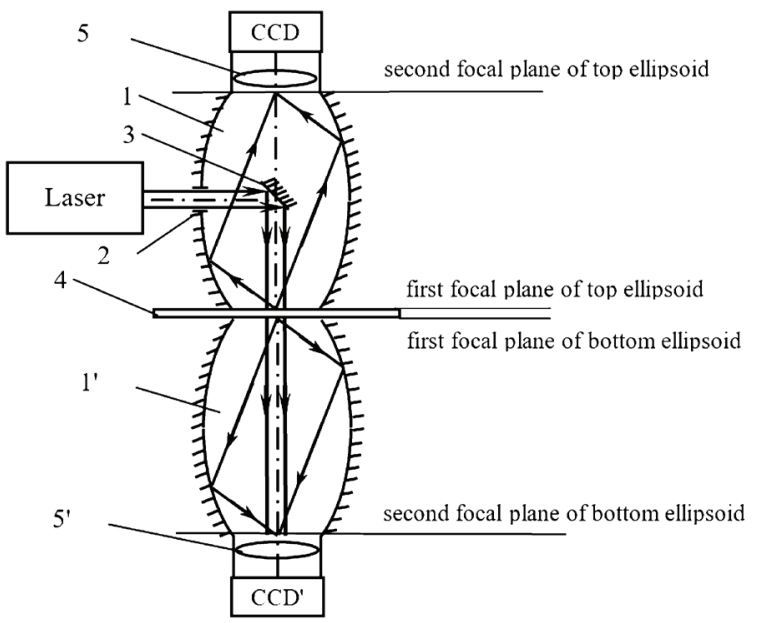

Figure 2 - Scheme of model photometer: top (1) and bottom (1') ellipsoidal reflector; source port (2); plane mirror (3); BM sample (4); the matching optical systems $\left(5,5^{\prime}\right)$
For comparison of images, that were received by real photometer and obtained during simulation in modeling photometer, it is necessary to apply appropriate filtering. It is necessary to separate from photometric images only part of radiation, which reflected from the internal mirror surface of reflector, so as other part of radiation does not go to $\mathrm{CCD}$ matrix. Thus, it is possible to consider the influence of objective optical system of real photometer as a result of numerical modelling. Radiation from the light source comes through the source port 2 to the plane mirror 3 , which is situated on the small axis of ellipsoid of revolution. In modeling experiment, the point of ray initiation is the plane mirror center, which coincides with mathematical center of ellipsoid, and initial weight of photons is reduced on the coefficient of reflection of mirror 3, which is used in real photometer.

\section{Results and discussion}

Modeling is performed by authorial developed specialized software. It represent adequately in both numerical comparison of calculated values of coefficients of diffuse reflection, absorption, and total transmittance; and analysis of photometric images of real and model experiments [17]. The quantity of emitted photons equals to 20 million for approximation of incident radiation parameters to possibilities of reception and registration system that use monochrome CCD camera. For three considered cases, separate photons sizes were adapted to form and size of photometric image pixels. The unit 
photons weight was modeled by white color, and smaller values - at grayscale. As a result of modeling, there was received a series of photo-metric images of second focal plane of top and bottom ellipsoids for separate layers of human skin with different thickness

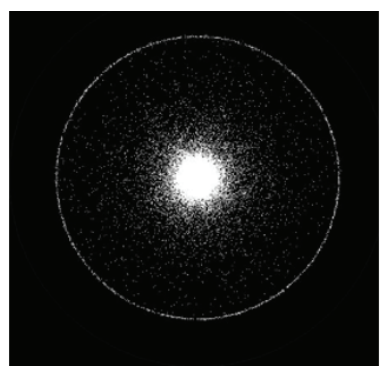

$a$

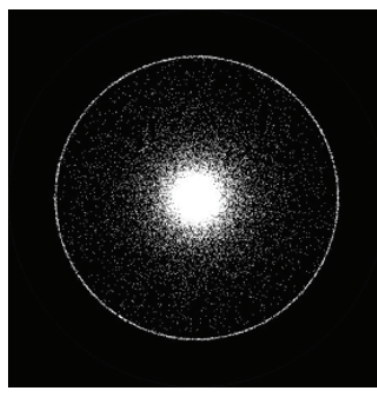

$b$

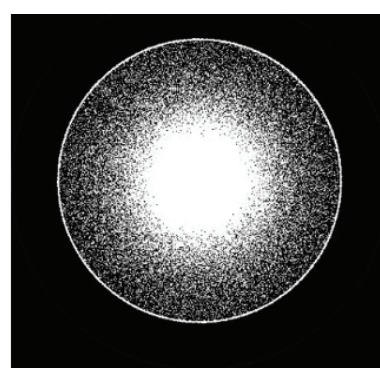

c

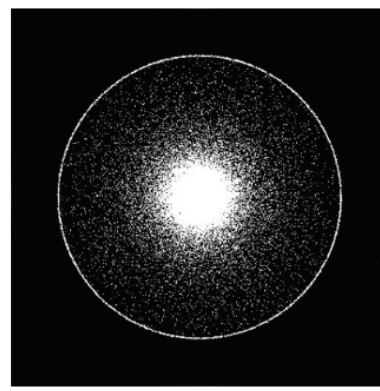

d
(Figure 3) considering the incident laser beam profiles. Photometric spatial distribution in second focal plane of top ellipsoid corresponds to backscattered light, and in second focal plane of bottom ellipsoid corresponds to forward scattered light.
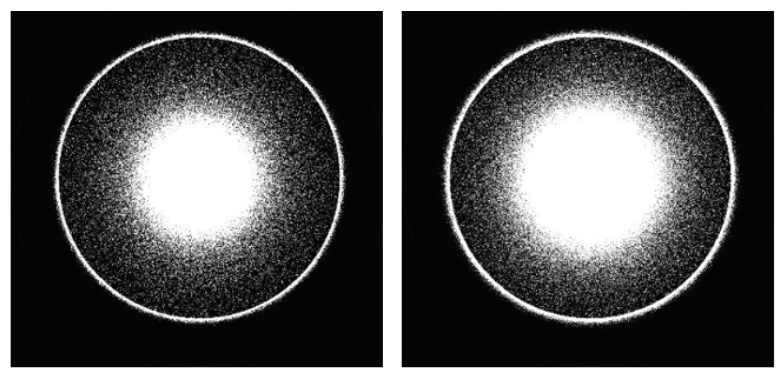

$f$

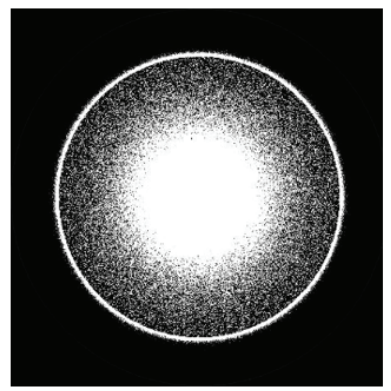

$h$

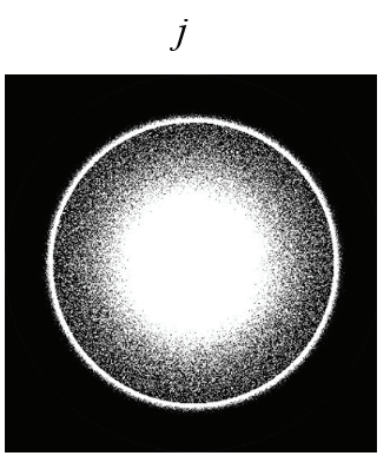

$k$

Figure 3 - Photometric images of forward and backscattered light for model with corneous layer thickness $0.02 \mathrm{~mm}$ $(a, b)$, epidermis with thickness $0.035 \mathrm{~mm}(c, d)$, derma with thickness $1.56 \mathrm{~mm}(f, h)$ and adipose tissue with thickness $2.12 \mathrm{~mm}(j, k)$, which corresponds to uniform intensity distribution of incident beam

Based on the zone-analysis principles of axially symmetrical images at ellipsoid photometry [18], there were received graphs of illuminance dependency (relation between intensity in pixels to area of corresponding zones) for middle and external rings of photometric images (Figures 4-7). Error of determination of illuminance in middle ring of photometric image $\alpha$ calculates as relative deviation of illuminance level in central circle in each series of

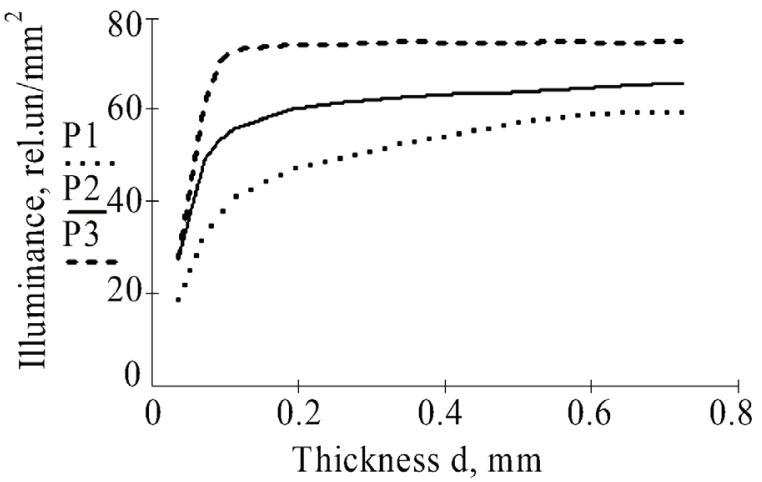

modal experiments, equals to $0.02 \%$ and $0.007 \%$ for corneous layer, $0.015 \%$ and $0.024 \%$ for epidermis, $0.004 \%$ and $0.003 \%$ for derma, 0.01 and $0.03 \%$ for adipose tissue in forward and backscattered respectively. Illuminance level of central circle is equable and includes collimated component, and component that characterizes main petal of light scattering diagram in forward and backward direction.

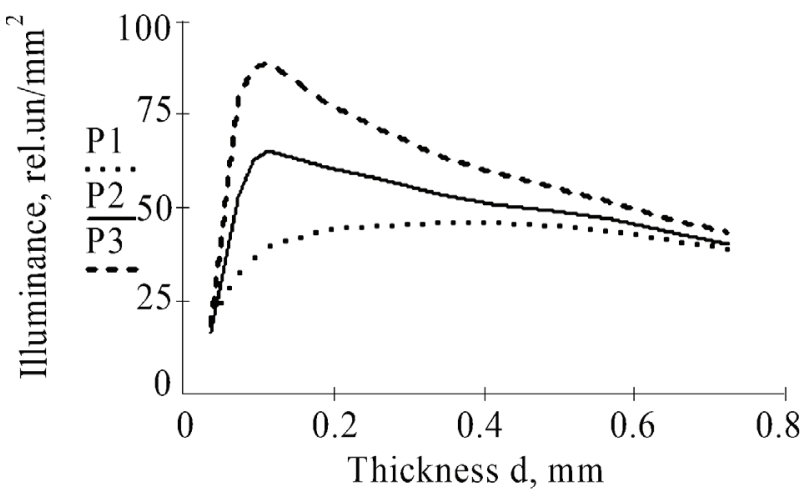

$b$ 


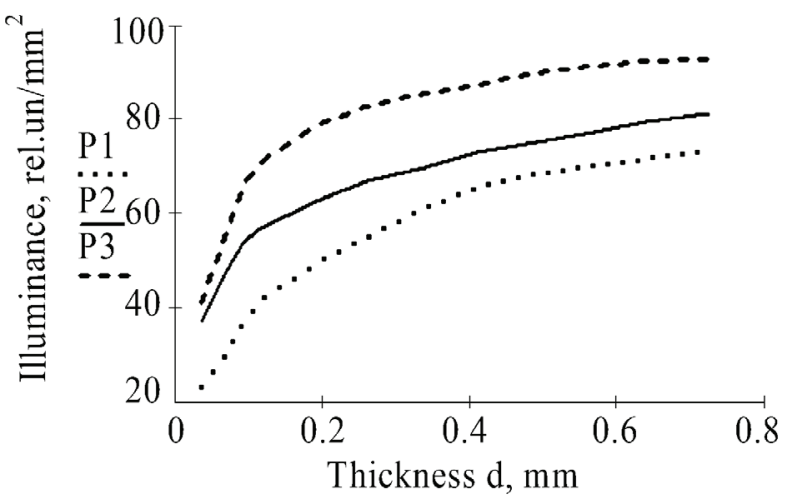

$c$

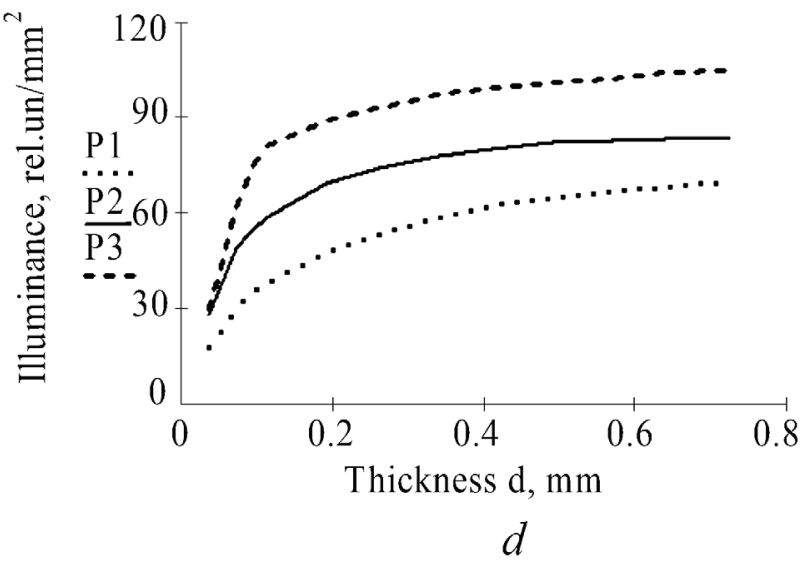

Figure 4 - Illuminance of the external and middle rings of photometric images for model of various thickness of corneous layer in forward $(a, b)$ and backscattered $(c, d)$ light respectively: $P 1$ - infinitely thin beam; $P 2$ - Gauss section beam; $P 3$ - uniform intensity beam

The mentioned error defines the accuracy photometric image central circle borders determination, where illuminance is equable, and correlate with sensitivity threshold value, expressed in Ref. [17], as $(100-\alpha) \%$. Parameters of mai

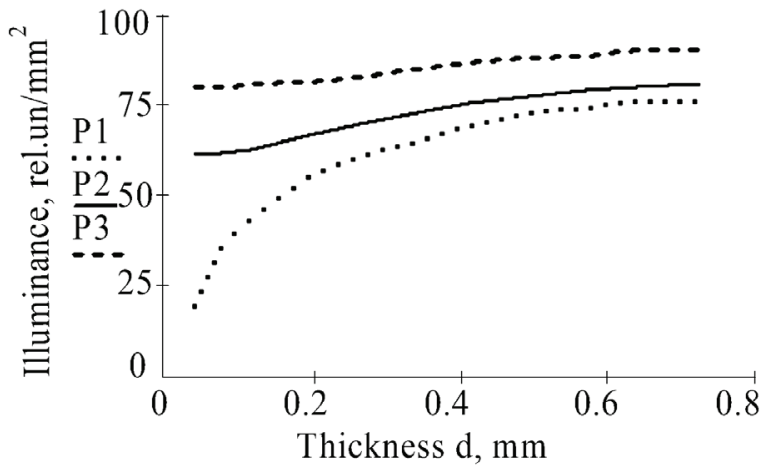

$a$

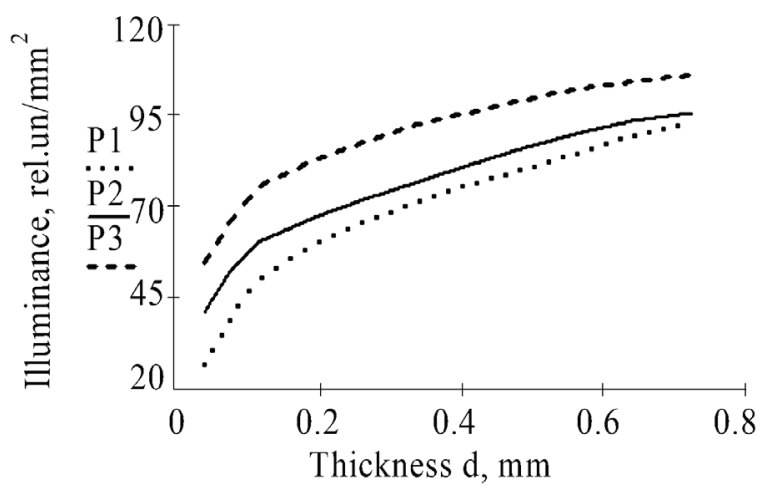

$c$ petal and middle ring can be used for investigation of scattering indicatrix by thick layers of BM, and therefore for determination of anisotropy factor of single scattering $[18,19]$. However, they were not considered in the current research.
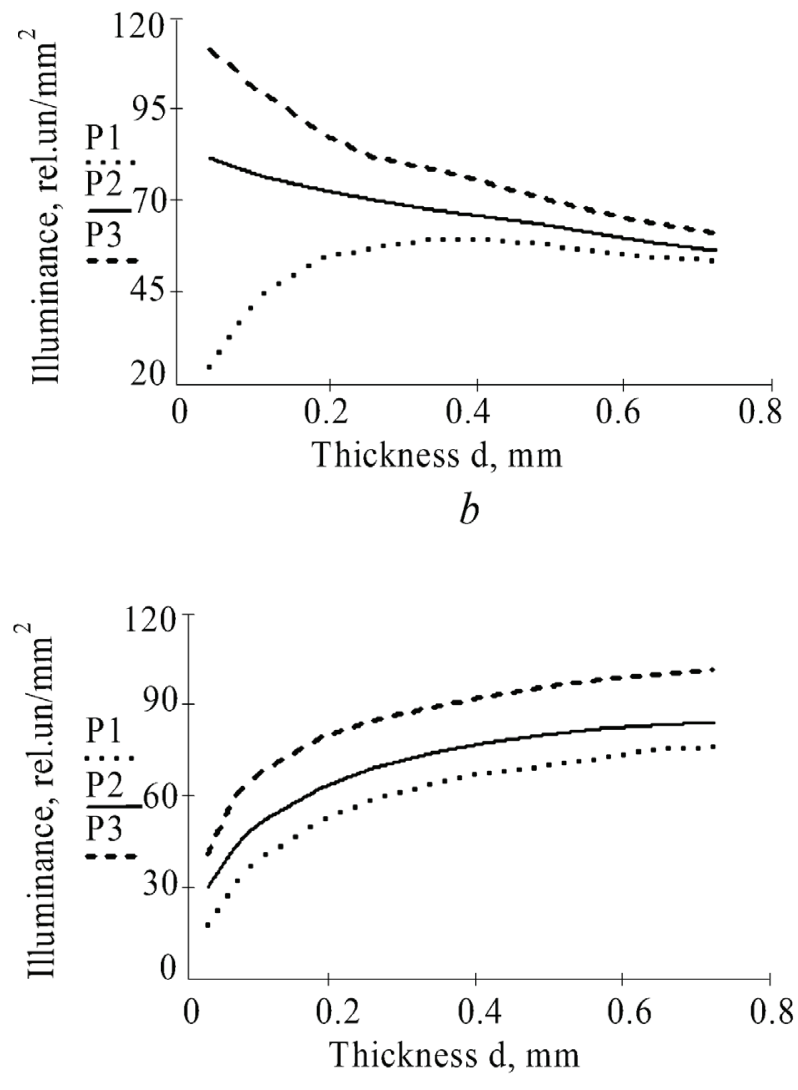

$d$

Figure 5 - Illuminance of the external and middle rings of photometric images for model of various thickness of epidermis in forward $(a, b)$ and back scattered $(c, d)$ light respectively: $P 1$ - infinitely thin beam; $P 2-$ Gauss section beam; $P 3$ - uniform intensity beam 


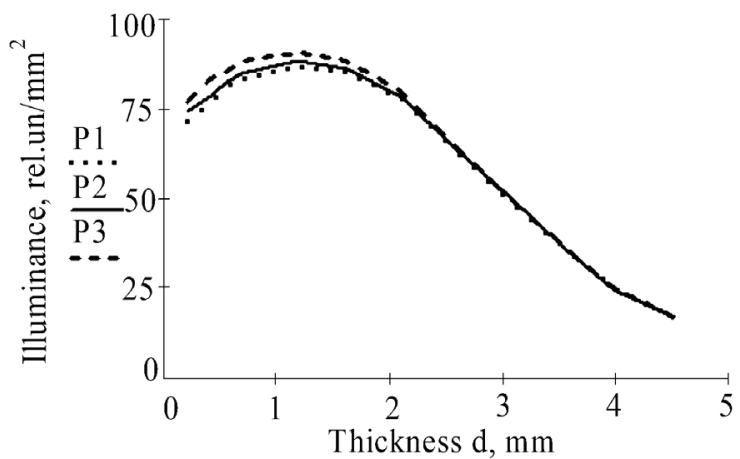

$a$

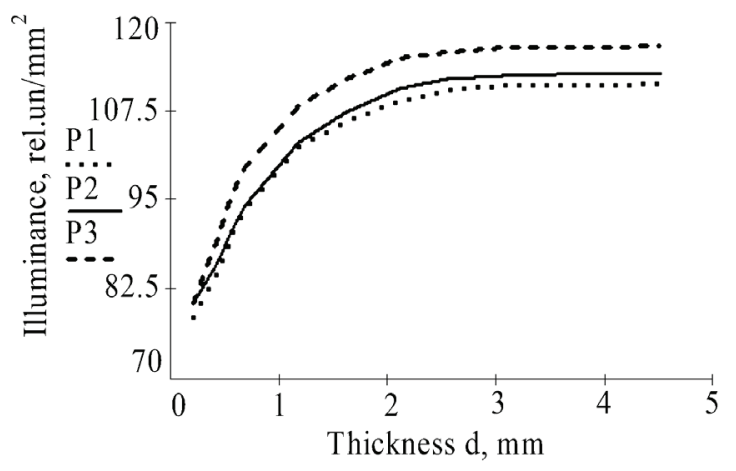

$c$

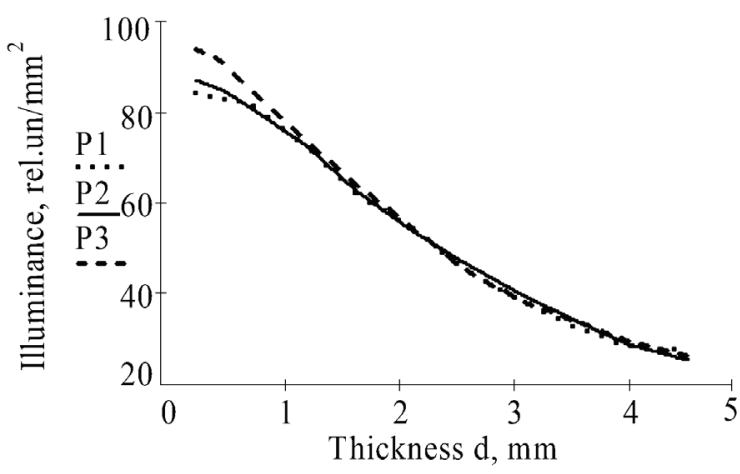

$b$

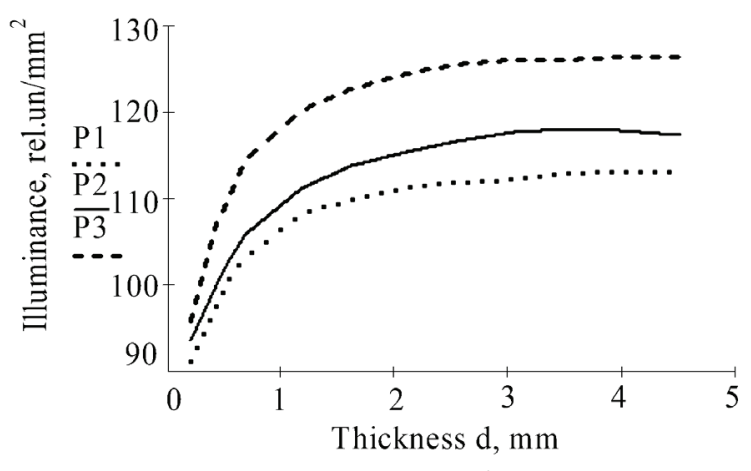

d

Figure 6 - Illuminance of the external and middle rings of photometric images for model of various thickness of derma in forward $(a, b)$ and back scattered $(c, d)$ light respectively: $P 1$ - infinitely thin beam; $P 2$ - Gauss section beam; $P 3$ uniform intensity beam

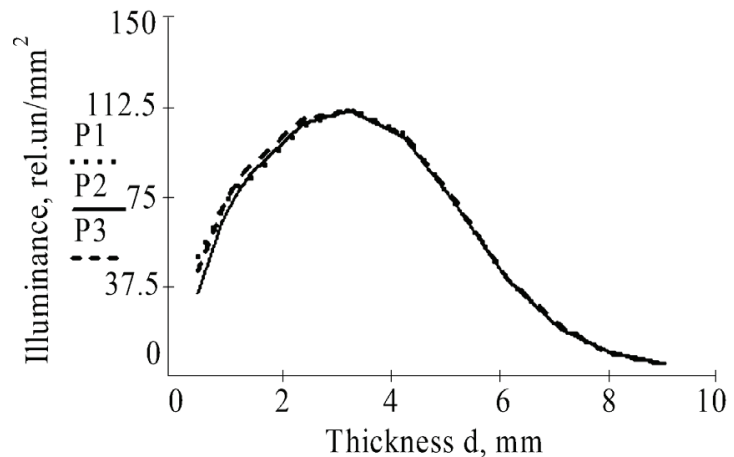

$a$

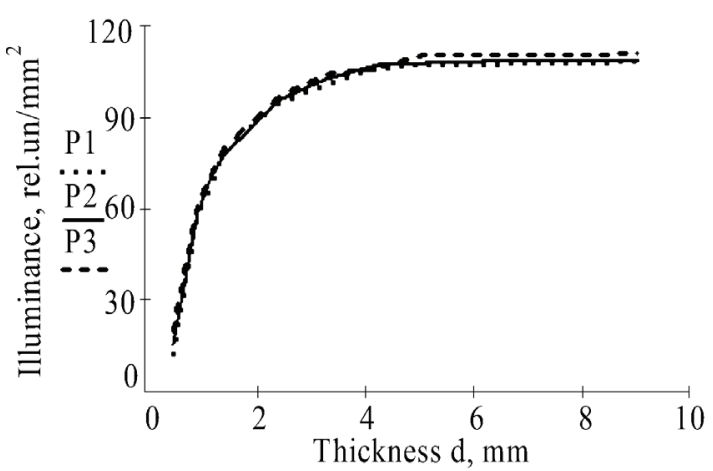

$c$

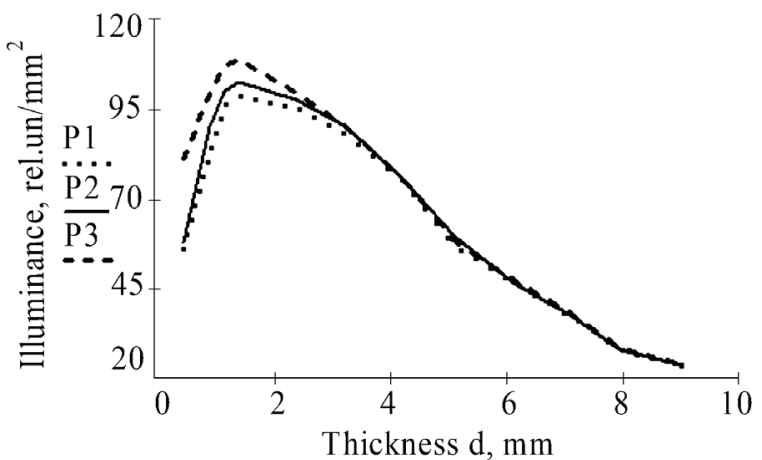

b

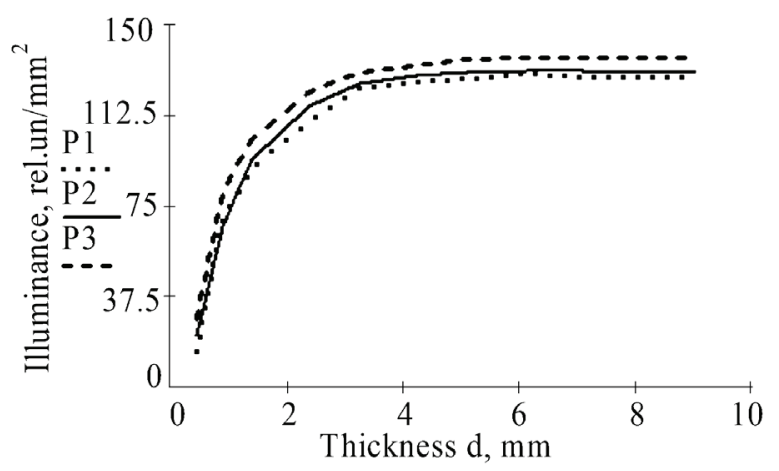

$d$

Figure 7 - Illuminance of the external and middle rings of photometric images for model of various thickness of adipose tissue in forward $(a, b)$ and back scattered $(c, d)$ light respectively: $P 1$ - infinitely thin beam; $P 2$ - Gauss section beam; $P 3$ - uniform intensity beam 
During the analysis of graphs, it is important to consider that real range of thickness change of investigated human skin layers is situated in the limits, described in the Table. That is the reason why the estimation of influence of incident beam profile on the spatial distribution of scattered radiation in photometric images (Figure 3) of separate layers is expedient to perform in mentioned thickness range of multi-layered structure. However, the combination of skin layers with different thicknesses in one modeling experiment can have too many variations.

Previous estimative tests of authors reveal that problem resolving require additional analytical basis. Thus, in current research it was analyzed influence of separate layers of human skin on spatial distribution at photometry by ellipsoidal reflectors.

There compares graphs of corneous layer (Figure 4) and epidermis (Figure 5) with dependency of different zones in photometric images of derma (Figure 6) and adipose tissue (Figure 7). Figures represent that in both reflected and transmitted light the transversal section of laser collimated beam significantly influences on the light distribution in both edge zone (external ring) and middle ring [17] of photometric image of corneous layer and epidermis. Thus, the profile of incident beam for these light scatter tissues will have crucial influence on light scattering of multi layered human skin structure regardless of the thickness of mentioned layers. At the same time, the influence of laser beam profile on adipose tissue in applied tasks of biomedical photometry by ellipsoidal reflectors will have no significant influence on light scattering. Thereby, the contribution of spatial distribution of scattered light by adipose tissue during investigation of multi layered skin structure can be represented by constant component of defined thickness. Atypical for this particular investigation is light scattering by derma (Figure 6). Moreover, the dependency of illuminance of forward scattered light from the beam profile is insignificant for almost all investigated thicknesses. This allows considering the radiation distribution effect in derma as constant component during creation of analytical model of forward light scattering. Thereby, the influence of incident beam profile on the light scattering in derma in forward direction is similar to light scattering of adipose tissue in forward and backward directions. At the same time, the influence of the laser profile on light scattering of derma in backward direction is similar to light scattering type in epidermis and corneous layer. Moreover, the influence of the profile on light scattering in forward direction for corneous layer is too big for small thickness of such BM, which will particularly influence on the investigation of human skin samples from lips, forehead, nose, breast genitals, belly, back, shoulder, forearm, and thigh [16].

Light of the middle ring and edge zone of graphs can be considered typical for different profiles of incident beam, because there observes typical correlation in mutual disposition of corresponding curves. Infinitely small profile of incident laser beam creates lower illuminance of corresponding zones of photometric images comparing to Gaussian profile. Uniform distribution of radiation intensity in transversal section leads to the highest illuminance level.

\section{Conclusion}

Current report represents results of numerical modeling illuminance distribution in different zones of photometric image for separate layers of human skin in forward and back scattered light during photometry by ellipsoid reflectors. Numerical modeling was performed by Monte-Carlo method, which was modified for photometry by ellipsoid reflectors, and considers profile of transversal distribution of probing laser radiation. Received results reveal that for strongly scattering layers of human skin (corneous layer and epidermis) the influence of the incident beam profile for anatomic thicknesses of these layers is considerable, and create the illuminance difference in both edge zone and middle ring of photometric image. The difference reaches more than $50 \%$ in forward scattered light, and $30 \%$ in backward scattered light. At the same time, for relatively weak scattering layers of human skin (derma and adipose tissue) the influence of the incident beam profile is considerable only for derma in reflected light and reaches $10-15 \%$. Mentioned features reveal the influence of profile of incident laser beam on light scattering effects in separate layers of human skin. This allow interpretation of such results during construction of photometers with ellipsoid reflectors for human skin investigation as a multi layered media in condition of in vitro or in vivo experiments.

\section{References}

1. Tuchin V.V. Opticheskaya biomeditsinskaya diagnostika [Optical biomedical diagnostics. In 2 parts. Part. 1. Translated from English]. Moscow, Physmathlit Publ., 2007, 560 p. (in Russian). 
2. Vo-Dinh Tuan. Biomedical Photonics Handbook II Vol., USA, CRC Press LLC, 2003, 889 p.

3. Baranoski G., Krishnaswamy A. An introduction to light interaction with human skin. RITA, 2004, no. 11 (1), pp. 33-62.

4. Pushkareva E. Metody matematicheskogo modelirovaniya $v$ optike biotkani [Methods of mathematical modeling in tissue optics]. St. Petersburg, ITMO Publ., 2008, 103 p. (in Russian).

5. Genina E. Metody biofotoniki: Fototerapiya [Methods of biophotonics: Phototherapy]. Saratov, Novyi Veter Publ., 2012, 119 p. (in Russian).

6. Bezuglyi M.A., Bezuglaya N.V. Ellipsoidal reflectors in biomedical diagnostic. Proc. SPIE, 2013, pp. 9032. doi: $10.1117 / 12.2044606$

7. Bezuglyi M.A., Bezuglaya N.V., Helich I.V. Ray tracing in ellipsoidal reflectors for optical biometry of media. Appl Opt., 2017, no. 56 (30), pp. 8520-8526. doi: $10.1364 / A O .56 .008520$

8. Bezuglyi M.A., Pavlovets N.V. Optical biometry of biological tissues by ellipsoidal reflectors. Proc. OSASPIE, 2013, pp. 8798. doi: 10.1117/12.2031142

9. Meglinskii I.V. Monte Carlo simulation of reflection spectra of random multilayer media strongly scattering and absorbing light. Quantum Electronics, 2001, no. 31, pp. 1101-1107. doi: 10.1070/QE2001v031n12ABEH002108

10. Prahl S.A., Keijzer M., Jacques S.L., Welch A.J. A Monte Carlo Model of Light Propagation in Tissue. Dosimetry of Laser Radiation in Medicine and Biology, 1989, SPIE Institute Series 5, pp. 102-111. doi: $10.1117 / 12.2283590$

11 Budagovsky A.V. Distantsionnoye mezhkletochnoye vzaimodeystviye [Distant intercellular interaction]. Moscow, Technika Publ., 2004, p. 104. (in Russian).
12. Florence Sudha G., T Ganesa Palnivelu. Electronic biopsy for skin cancer detection. Current science, 2004, no. 87 (5), pp. 645-649.

13. Bashkatov A.N., Genina E.A., Kochubey V.I. and Tuchin V.V. Optical properties of human skin, subcutaneous and mucous tissues in the wavelength range from 400 to 2000 nm. J. Phys. D Appl. Phys., 2005, no. 38 (15), pp. 2543-2555. doi: $10.1142 / \mathrm{S} 1793545811001319$

14. Cui W., Ostrander L.E. The relationship of surface measurements to optical properties of layered biological media. IEEE Trans. Biomed. Eng., 1992, no. 39, pp. 194201. doi: $10.1109 / 10.121651$

15. Kozhemiako V., Pavlov S., Stanchuk K. Optykoelektronni metody $i$ zasoby dlya obrobky ta analizu biomedychnykh zobrazhen': Monohrafiya [Opticalelectronic methods and technics for treatment and analysis of biomedical images. Monography]. Vinnytsia, Universum, 2006, 203 p. (in Ukrainian).

16. Yeliseyev Yu. Zabolevaniya kozhi. Polnyy meditsinskiy spravochnik dlya vsey semi [Skin diseases: A complete medical reference book for the whole family]. Moscow, Eksmo Publ., 2009, 802 p. (in Russian).

17. Bezuglyi M.A., Bezuglaya N.V., Samilyak A.B. [Image processing at ellipsoidal photometry]. Devices and methods of measurements, 2016, no. 7, pp. 67-76 [in Russian]. doi: 10.21122/2220-9506-2016-7-1-67-76

18. Jacques S. L. Optical properties of biological tissues: a review. Phys. Med. Biol., 2013, vol. 58, pp. R37R61. doi: 10.1088/0031-9155/58/11/R37

19. Hall G., Jacques S.L, Eliceiri K.W., Campagnola P.J. Goniometric measurements of thick tissue using Monte Carlo simulations to obtain the single scattering anisotropy coefficient. Biomedical optics express, 2012, no. 3 (11), pp. 2707-2719. doi: 10.1364/BOE.3.002707 